\title{
PERANCANGAN PROMOSI EVENT TEATER BONEKA SEBAGAI KAMPANYE TOLERANSI BERAGAMA
}

\author{
Saskia Putri Agustine, Nina Nurviana, Miki Tjandra \\ (Email: saskiagustine@gmail.com) \\ Desain Komunikasi Visual \\ Fakultas Seni Rupa dan Desain \\ Universitas Kristen Maranatha \\ Jl. Prof. drg. Suria Sumantri No. 65, Bandung, Indonesia
}

\begin{abstract}
ABSTRAK
Indonesia merupakan negara yang mengakui keberadaan enam agama. Namun, sayangnya, keberagaman ini masih disikapi dengan sikap-sikap intoleran yang dilakukan pemeluk agama mayoritas di berbagai daerah, salah satunya Jawa Barat. Selama lima tahun berturut-turut (20092014), Jawa Barat menempati peringkat tertinggi dalam jumlah kasus intoleransi beragama. Oleh karena itu, pendidikan toleransi terhadap agama lain penting diberikan sejak dini, terutama bagi masyarakat kelas menengah bawah yang memiliki pendidikan relatif rendah. Tujuan perancangan ini adalah untuk menanamkan nilai toleransi terhadap agama lain bagi anak Islam usia dini sebagai pemeluk agama mayoritas dengan memperkenalkan keberadaan agama lain di Indonesia melalui cerita dongeng dengan alat peraga boneka. Manfaat perancangan ini adalah agar anak mampu memahami dan menerima konsep perbedaan agama sehingga tercipta generasi yang mampu menghormati agama lain. Cerita dalam teater boneka ini memiliki enam karakter sebagai representasi enam agama yang ada di Indonesia. Kegiatan ini dipromosikan dengan menggunakan motion graphic dan booklet serta dilengkapi dengan gimmick.
\end{abstract}

Kata kunci: anak usia dini; Islam; kampanye; teater boneka; toleransi beragama

\begin{abstract}
Indonesia acknowledges the existence of six religions. However, this diversification is often met with some intolerance by the religion of majority in different regions, one of the examples of which is West Java. For five consecutive years (2009-2014), West Java is on the first rank of religion intolerance. Thus, the knowledge of tolerance towards the other religions needs to be implemented since the early age, particularly those coming out of modest families. The purpose of this design is to grow the essence of religion tolerance for the Moslems as the majority so that they can get to know the other religions in Indonesia via stories narrated through displays. The purpose is to make people willing to accept divergence of religion and to eventually make generations able to cope up with and respect religions with distinct concepts with one another. The approach implemented is to retell fairy tales with puppets as the representation and media. The puppets embody six different characters metaphorically symbolizing six different religions in Indonesia. This activity is promoted by making use of motion graphic and booklets as well as gimmick as complements.
\end{abstract}

Keywords: campaign; children of early age; Islam; puppet show; religion tolerance 


\section{PENDAHULUAN}

Sebagai negara majemuk, Indonesia mengakui keberadaan enam agama yaitu Islam, Katolik, Kristen Protestan, Hindu, Budha, dan Kong Hu Cu. Namun, keberagaman ini masih disikapi berbagai tindakan intoleransi mulai dari penolakan pendirian tempat ibadah, penghalangan pelaksanaan ritual ibadah, diskriminasi hingga kekerasan yang dilakukan oleh pemeluk agama mayoritas. Terjadinya kasus-kasus tersebut seharusnya menyadarkan masyarakat akan pentingnya sikap saling menghormati antar pemeluk agama, terutama di kalangan menengah bawah dengan tingkat pendidikan yang rendah.

Pendidikan toleransi terhadap agama lain ini perlu ditanamkan sejak dini agar dapat menciptakan generasi penerus bangsa yang memiliki kerukunan umat beragama. Dalam periode keemasannya, anak perlu diberikan pemahaman yang tepat bahwa perbedaan agama bukanlah alasan untuk menimbulkan perselisihan. Setiap pemeluk agama dapat hidup dalam keharmonisan dengan tetap menjalankan keyakinannya masing-masing. Dengan diberikan pemahaman tersebut, anak diharapkan memiliki dasar untuk menghadapi pengaruh fanatisme yang seolah menghalalkan kekerasan dan penindasan terhadap agama lain di masa depan. Pentingnya pendidikan toleransi terhadap agama lain juga diatur dalam Peraturan Mendikbud Nomor 58 Tahun 2009. Dalam peraturan tersebut, menghormati agama orang lain merupakan salah satu standar tingkat pencapaian perkembangan pada anak usia Taman Kanak-Kanak. Meskipun memahami akan pentingnya pendidikan toleransi terhadap agama lain, kebanyakan orang tua dari kalangan menengah bawah sangat jarang menanamkan nilai toleransi ini kepada anak-anaknya. Orang tua cenderung mengandalkan pihak sekolah untuk mengajarkan toleransi tersebut. Sayangnya, sekolah sebagai lembaga yang diandalkan pun lebih sering mengajarkan nilai-nilai moral dan agama seperti ibadah, tata karma, atau kesopanan. Media yang beredar saat ini pun lebih banyak yang mengajarkan nilai-nilai moral dan agama yang berkaitan dengan diri sendiri, teman, dan orang tua. Tidak banyak media yang mengajarkan tentang hubungan anak muslim dengan orang lain yang berbeda agama. Toleransi terhadap agama lain menjadi materi yang jarang diajarkan kepada anak akibat minimnya media dan tidak adanya lingkungan untuk melakukan pembiasaan secara langsung.

Mendongeng dengan alat peraga seperti boneka merupakan kegiatan yang dapat dijadikan alternatif untuk menggantikan pembiasaan. Mendongeng dengan boneka dapat membuat anak merasa lebih terlibat langsung dengan cerita yang disampaikan. Selain itu, kegiatan ini dapat dilakukan dengan jumlah anak yang banyak untuk mendukung kecenderungan 
orang tua dan anak dari kalangan menengah bawah yang gemar berkumpul dengan teman teman di lingkungan sekitarnya.

\section{METODE PENELITIAN}

Perancangan dibuat berdasarkan penelitian yang dilakukan dengan metode kualitatif yaitu wawancara dan observasi. Wawancara dilakukan kepada pemuka agama untuk mengetahui pandangan agama Islam mengenai toleransi terhadap agama lain. Wawancara juga dilakukan kepada Dinas Pendidikan Kota Bandung, guru satuan PAUD, dan psikolog untuk memahami pendidikan anak usia dini dan media belajar yang tepat. Observasi dilakukan di satuan PAUD untuk mengetahui minat anak usia dini terhadap visual. Observasi juga dilakukan di toko buku untuk mengetahui media belajar anak usia dini yang telah beredar. Selain metode kualitatif, dilakukan juga metode kuantitatif berupa kuesioner yang dibagikan kepada orang tua yang memiliki anak usia dini 4-6 tahun. Kuesioner ini digunakan sebagai data tambahan mengenai topik dan untuk menentukan media perancangan serta promosi.

Dalam penelitian ini dilakukan studi pustaka untuk mencari referensi dan teori yang mendukung perancangan, yaitu:

1. Toleransi terhadap agama lain dalam Islam

2. Pendidikan anak usia dini

3. Perkembangan anak usia dini

4. Teori kampanye

5. Teori event

6. Teori ilustrasi

7. Teori pertunjukan boneka

8. Teori cerita anak

\section{PEMBAHASAN}

Pendidikan toleransi terhadap agama lain merupakan faith development bagi anak usia dini. Pada tahap ini, anak memahami Tuhannya berdasarkan pengetahuan yang diberikan oleh pihak otoritas, seperti guru dan orang tua. Anak usia dini berpikir secara konkrit-praktis atau diibaratkan seperti kertas polos yang sangat mudah diisi. Jika mereka diajarkan tentang kejelekan agama orang lain, maka mereka akan berpikir bahwa agama orang lain lebih buruk dari agama mereka. Pemahaman seperti inilah yang akan memunculkan sikap intoleran. Sebaiknya pada anak usia dini diajarkan kebaikan-kebaikan semua agama yang 
bersifat universal seperti kasih sayang. Namun, bukan berarti anak diajarkan bahwa semua agama sama dan dapat dicampur adukkan. Konsep pencampuran itu berbahaya dan dapat menjerumuskan pemahaman anak. Setiap anak harus tetap memiliki identitas sesuai agama mereka masing-masing, tetapi harus dapat bersosialisasi dengan pemeluk agama lain tanpa megedepankan perbedaan agamanya. Oleh karena itu, pengajaran toleransi ini harus didasarkan pada suatu ajaran agama tertentu.

Menghormati agama lain sebaiknya diajarkan sejak dini, sesuai dengan standar pencapaian pengembangan anak yang telah diatur oleh pemerintah. Berdasarkan kuesioner yang dibagikan, 68 dari 100 responden juga berpendapat bahwa pendidikan toleransi terhadap agama lain perlu diberikan sejak usia Taman Kanak-Kanak. Sayangnya, di satuan PAUD menengah bawah materi ini paling jarang disampaikan kepada anak didik karena mayoritas anak didik memiliki agama yang sama sehingga penyampaian materi tidak dapat dilakukan melalui pembiasaan.

Bagi anak usia dini, penyampaian lewat cerita lebih efektif dibandingkan penyampaian secara langsung. Anak usia dini juga perlu diberikan figur atau karakter yang dapat dijadikan panutan. Mendongeng dengan alat peraga seperti boneka merupakan kegiatan yang dapat dijadikan alternatif untuk menggantikan pembiasaan tersebut. Mendongeng dengan boneka dapat membuat anak merasa lebih terlibat langsung dengan cerita yang disampaikan. Selain itu, kegiatan ini dapat dilakukan dengan jumlah anak yang banyak melalui sebuah event untuk mendukung kecenderungan orang tua dan anak dari kalangan menengah bawah yang gemar berkumpul dengan teman-teman di lingkungan sekitarnya.

Perancangan kampanye ini ditargetkan kepada anak muslim usia dini karena Islam merupakan agama mayoritas di Indonesia. Target berasal dari status ekonomi menengah bawah karena kalangan ini memiliki tingkat pendidikan yang relatif rendah sehingga lebih mudah dipengaruhi oleh fanatisme. Berdasarkan kuesioner, orang tua menengah beranggapan bahwa kondisi toleransi beragama di Indonesia telah memasuki tahap memprihatinkan. Dari sisi psikografis, para orang tua menghabiskan waktu khusus setiap hari untuk anak, memilih cerita sebagai media belajar, dan suka mengikuti kegiatan sekitar. Media utama yang diakses oleh anak usia dini kelas menengah bawah ini adalah televisi dengan kartun sebagai jenis tayangan kesukaan.

Berdasarkan analisis dari data yang telah dikumpulkan, maka targeting perancangan ini adalah: 


\section{Target Primer}

a. Demografi: anak-anak muslim usia 4-6 tahun berjenis kelamin laki-laki dan perempuan yang tinggal di Kota Bandung.

b. Status ekonomi: memiliki orang tua muslim dengan status ekonomi sosial menengah ke bawah.

c. Psikografis: anak-anak yang senang diberi cerita dan suka menonton tayangan kartun di televisi.

2. Target Primer

a. Demografi: pria dan wanita muslim berusia 27-35 tahun yang memiliki anak usia 4-6 tahun dan tinggal di Kota Bandung, Indonesia.

b. Status ekonomi: menengah ke bawah.

c. Psikografis: memahami pentingnya pendidikan toleransi terhadap agama lain bagi anak usia dini, memilih cerita sebagai media untuk mendidik anak, meluangkan waktu khusus untuk anak setiap hari, dan suka mengikuti kegiatan di lingkungan sekitar.

Positioning perancangan kampanye ini adalah event panggung boneka pertama yang mengajarkan toleransi antar umat beragama bagi anak usia dini dengan basis Islam di Kota Bandung.

Strategi media yang digunakan adalah:

1. Tahap awareness: motion graphic berupa iklan televisi dan poster yang dipasang di posyandu serta satuan-satuan PAUD.

2. Tahap informing: flyer yang dibagikan langsung pada orang tua dan poster event yang dipasang di posyandu serta satuan-satuan PAUD. Saat event dilangsungkan di satuansatuan PAUD, target diberi booklet yang berisi cerita.

3. Tahap reminding: boneka jari sebagai pelengkap booklet yang dapat digunakan ketika mendongeng di rumah dan sticker.

Kata kunci dari konsep visual perancangan ini adalah anak-anak, ceria, kebersamaan, dan Islam. Dari tahap awareness menuju reminding, latar langit pada media-media berubah dari siang ke malam untuk menunjukkan bahwa rasa toleransi harus dimiliki kapan saja. Visual yang diterapkan mencerminkan kesan ceria dan memunculkan rasa kebersamaan dari tokoh-tokohnya. Sebagai event khusus muslim, kesan keislaman ditonjolkan melalui bentukan kubah mesjid dan motif arabesque.

Event ini diberi nama Aku Muslim Toleran untuk menandakan adanya pemahaman dan 
pengakuan dari anak bahwa sebagai seorang muslim, dirinya memiliki sikap toleran terhadap agama lain. Media visual yang dirancang dalam pelaksanaan event ini adalah panggung, boneka tangan, panduan untuk dalang, backdrop, umbul-umbul, $x$-banner, name tag, kaos kru, dan gimmick berupa boneka jari serta sticker. Event dilaksanakan dalam rangkaian roadshow ke satuan-satuan PAUD menengah bawah di Kota Bandung sebagai peringatan Hari Toleransi Internasional yang jatuh pada tanggal 16 November.

Logotype 'Aku Muslim Toleran' memiliki bentuk yang membulat dan saling merangkul untuk memberi kesan anak-anak, dinamis, dan melambangkan kebersamaan. Logogram berupa enam anak melambangkan enam agama yang saling berdampingan, merangkul dan rukun. Bahasa Arab 'tashamuh' yang berarti 'membiarkan sesuatu untuk dapat saling mengizinkan dan saling memudahkan' (toleransi) diletakkan di dasar logo sebagai tanda bahwa event ini berbasis pada ajaran Islam. Warna hijau melambangkan Islam, sedangkan jingga melambangkan kebersamaan. Warna pelangi pada logogram melambangkan keberagaman yang harmonis.

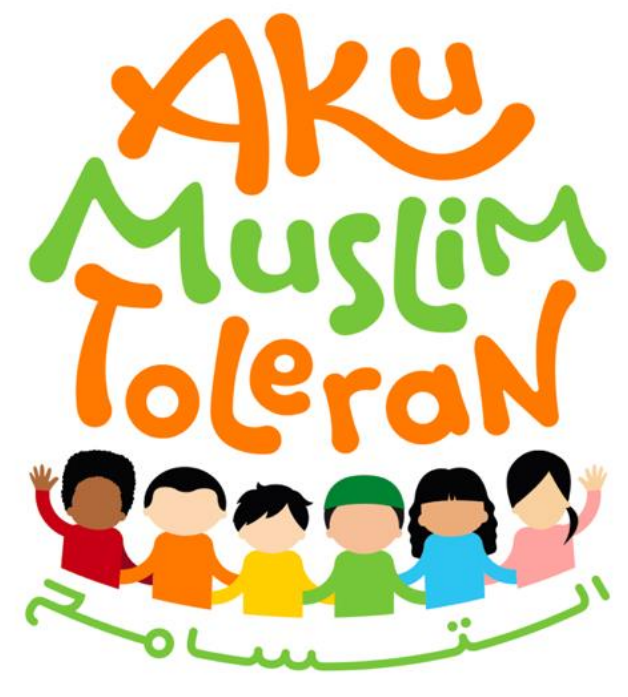

Gambar 1. Logo Aku Muslim Toleran

Dalam cerita, terdapat enam karakter utama sebagai representasi enam agama di Indonesia. Kepala karakter dirancang berdasarkan bentuk geometri seperti lingkaran, elips, dan persegi panjang serta memiliki gaya rambut yang berbeda-beda agar mudah dibedakan oleh anak. Selain bentuk, pemberian warna yang berbeda-beda juga membantu memudahkan anak dalam mengenali karakter. Masing-masing tokoh yang terdapat pada cerita panggung boneka ini memiliki ciri masing-masing agama yang digambarkan secara implisit dan 
bersifat relatif universal agar tidak menyinggung.

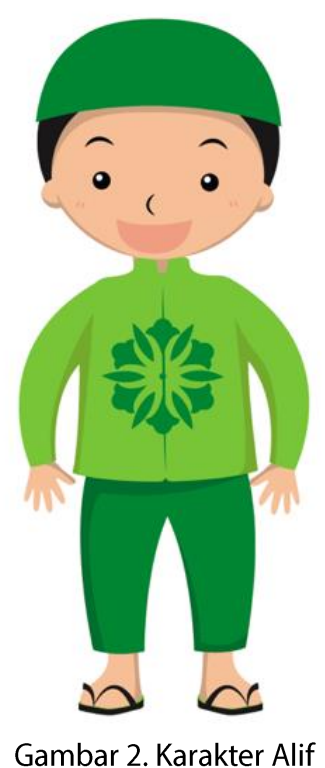

Karakter Alif merupakan karakter beragama Islam. Sebagai ciri agamanya, Alif menggunakan baju taqwa dan peci berwarna hijau serta motif arabesque yang sering ditemukan di bangunan mesjid.

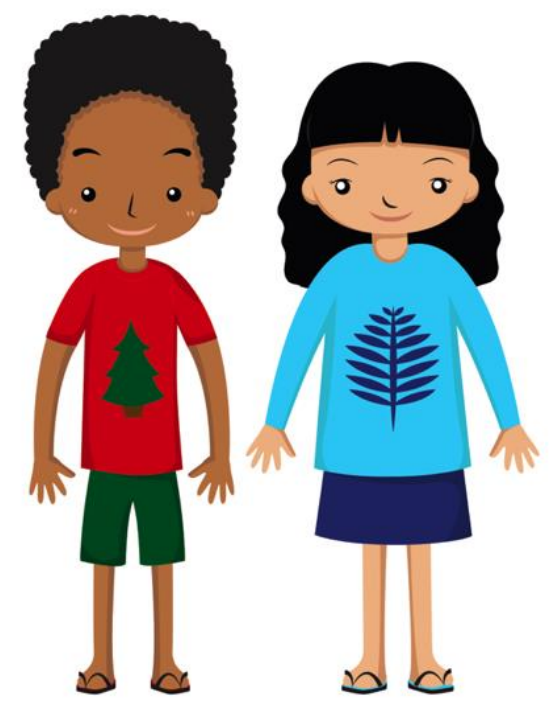

Gambar 3. Karakter Justin dan Alena

Justin adalah karakter beragama Kristen Protestan, sedangkan Alena adalah karakter yang beragama Katolik. Justin memiliki simbol pohon natal dan Alena memiliki simbol daun. Kedua tokoh ini juga memiliki kulit gelap dan rambut ikal karena mayoritas pemeluk umat agama ini terdapat di Indonesia bagian timur. 


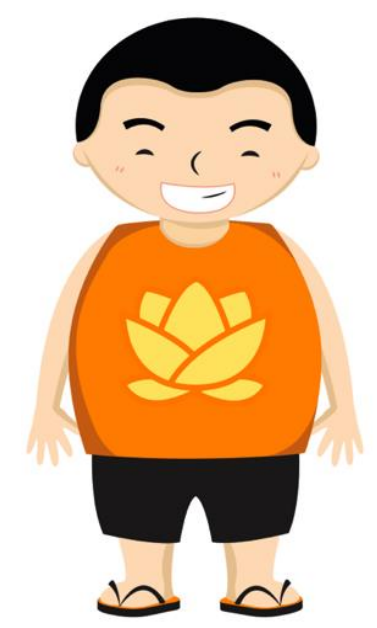

Gambar 4. Karakter Buddhi

Buddhi adalah karakter beragama Buddha dengan simbol bunga teratai.

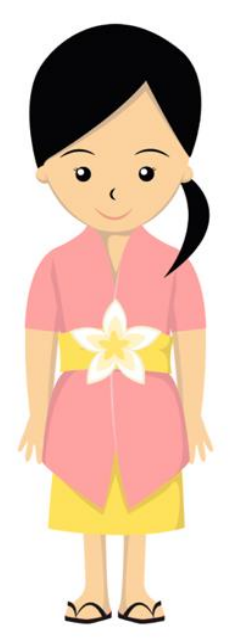

Gambar 5. Karakter Shanti

Shanti adalah tokoh beragama Hindu. Shanti menggunakan kebaya dan bunga Jepun Bali (Kamboja) karena mayoritas pemeluk Hindu di Indonesia terdapat di Provinsi Bali. 


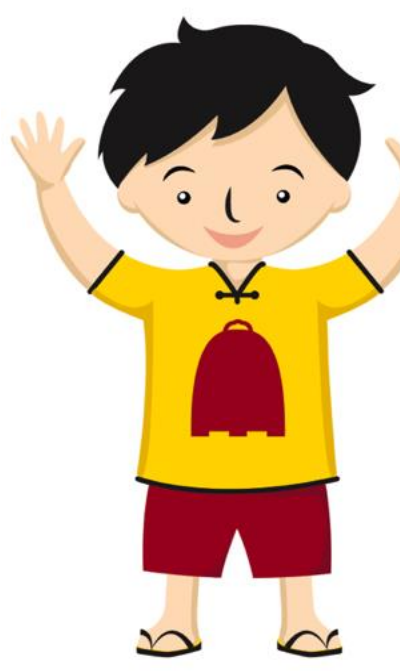

Gambar 6. Karakter Alvin

Alvin adalah karakter beragama Kong $\mathrm{Hu} C \mathrm{Cu}$ yang menggunakan cheongsam untuk melambangkan mayoritas pemeluknya yang berasal dari etnis Tionghoa. Cheongsam juga melambangkan negara asal agama Kong $\mathrm{Hu} C u$, yaitu China. Karakter ini memiliki simbol genta yang merupakan lambang agama Kong $\mathrm{Hu} \mathrm{Cu}$ di Indonesia. Karakter ini adalah karakter terkecil untuk melambangkan bahwa Kong $\mathrm{Hu} \mathrm{Cu}$ merupakan agama paling muda di Indonesia.

Komunikasi dilakukan melalui cerita yang terdapat dalam teater boneka dan booklet yang dibagikan. Kedua media ini memperkenalkan keberadaan dan ritual sehari-hari yang dimiliki tiap-tiap agama. Bahasa dan cerita dibuat sederhana sehingga anak dapat membayangkan dan dapat menyerap cerita yang diterima.

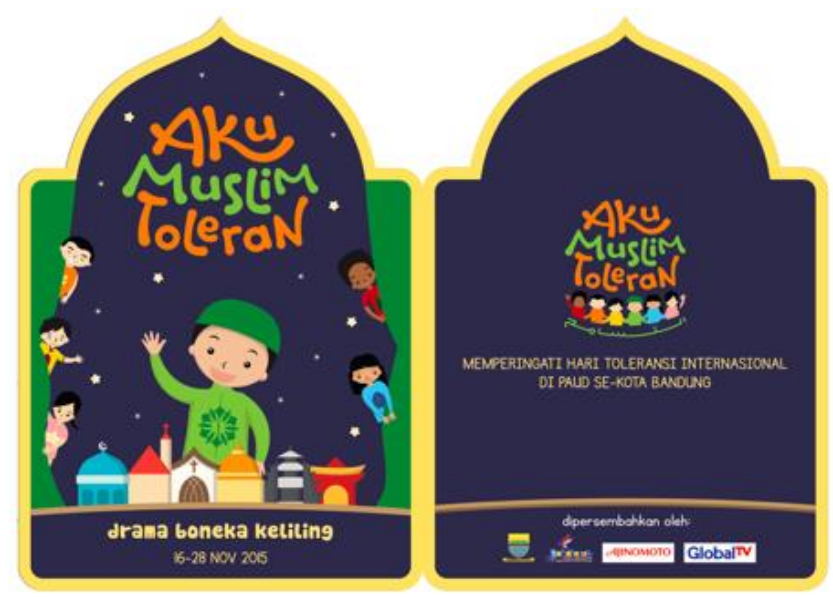

Gambar 7. Sampul Depan dan belakang booklet 


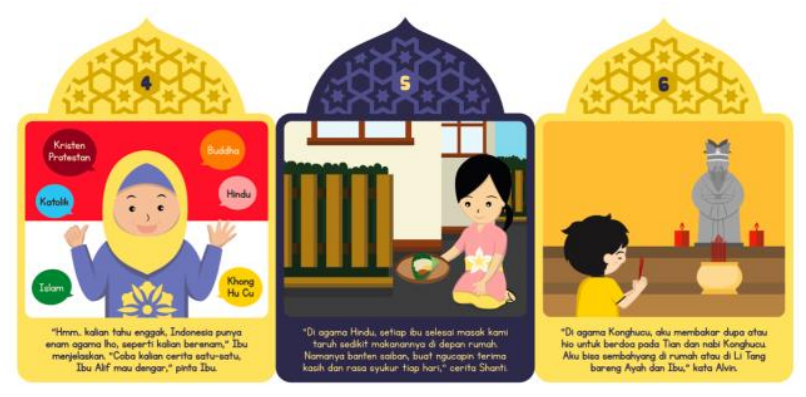

Gambar 8. Halaman yang menceritakan agama Hindu dan Kong $\mathrm{Hu} \mathrm{Cu}$

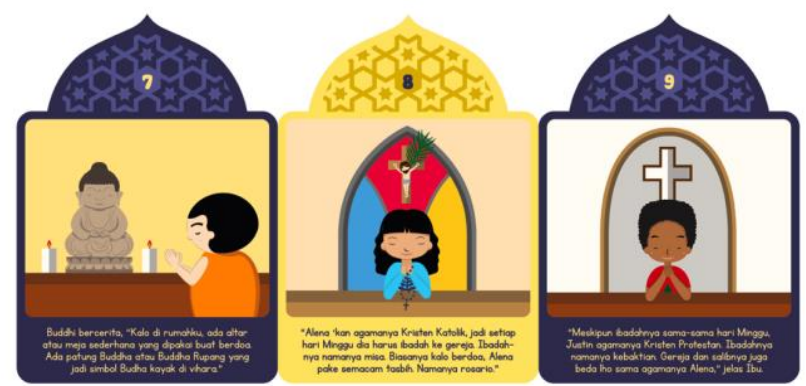

Gambar 9. Halaman yang menceritakan agama dan Buddha, Katolik dan Kristen Protestan

Dalam cerita dikisahkan Alif, Buddhi, Shanti dan Alvin sedang bermain bersama tanpa Justin dan Alena. Keempat anak ini tidak mengajak Justin dan Alena karena setiap hari Minggu keduanya tidak pernah ikut bermain bersama. Mendengar keluhan anak-anak, ibu Alif kemudian menjelaskan mengenai keberadaan enam agama di Indonesia dan meminta anak-anak untuk menceritakan ritual atau kegiatan keagamaannya satu per satu. Setelah anak-anak mendengar cerita tiap-tiap agama, mereka pun memahami bahwa mereka harus dapat menghargai perbedaan. Keempat sahabat ini pun meminta maaf pada Justin dan Alena, kemudian bermain bersama kembali.

Event ini dipromosikan kepada anak-anak melalui orang tua dan satuan-satuan PAUD. Media promosi yang digunakan adalah poster, flyer dan iklan televisi. Visual pada poster dan flyer menggambarkan anak-anak yang berada di panggung boneka. Pada tahap awareness, poster menunjukkan anak-anak yang bersembunyi di balik tirai untuk membangun rasa penasaran. Pada poster informing, anak-anak bersembunyi di balik tirai sudah lebih terbuka. Pada booklet, tirai sudah terbuka sepenuhnya. Tahap-tahap pembukaan tirai ini dirancang untuk menunjukkan kesinambungan dari tahap awareness hingga reminding. Desain flyer disesuaikan dengan desain poster informing. 


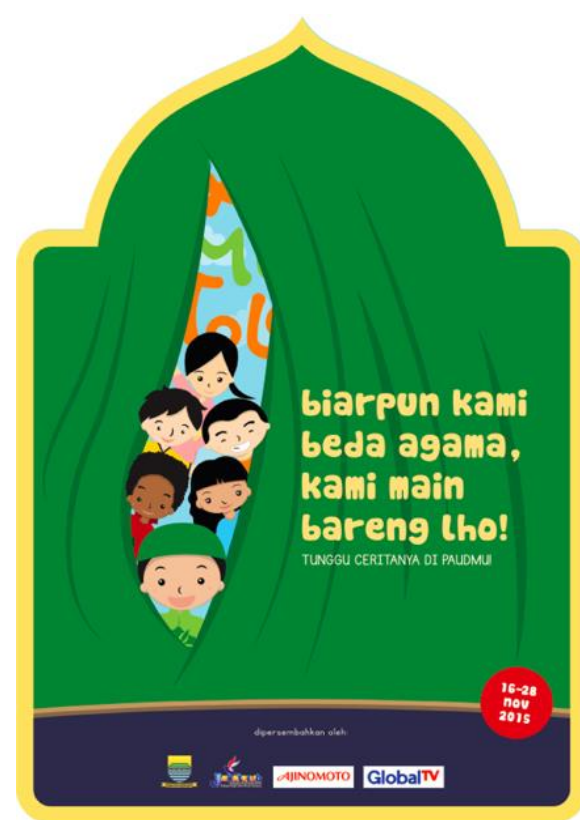

Gambar 10. Poster awareness

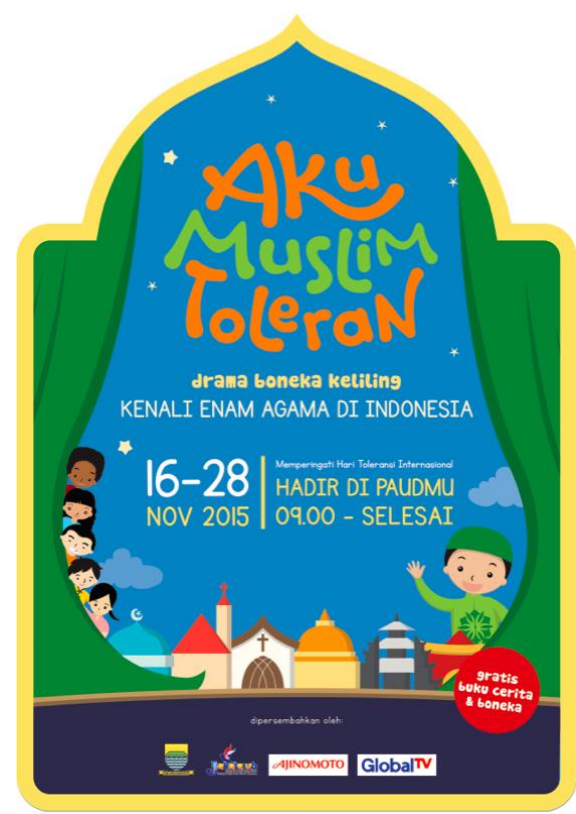

Gambar 11. Poster informing 


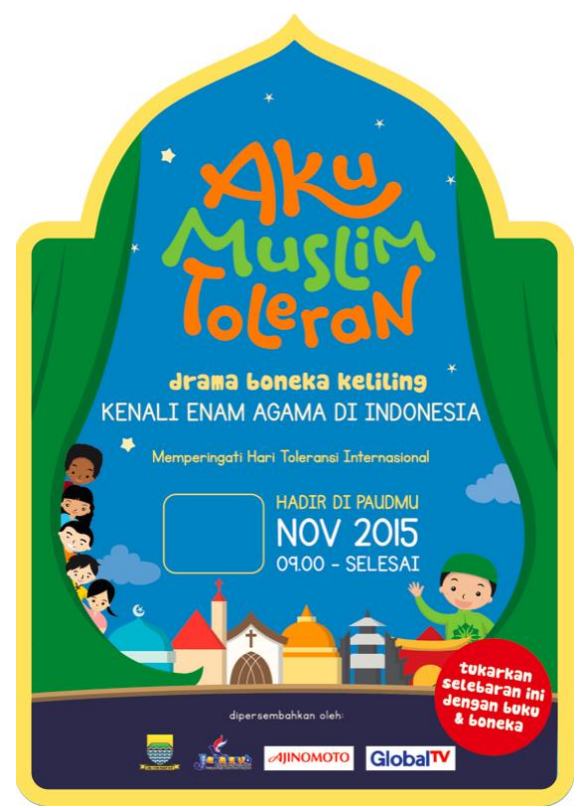

Gambar 12. Flyer

\section{PENUTUP}

Pendidikan toleransi terhadap agama lain sangat penting diberikan sejak dini karena Indonesia merupakan negara yang mengakui keberadaan enam agama. Sikap-sikap intoleransi yang terjadi seharusnya menyadarkan masyarakat mengenai pentingnya memahami perbedaan sedini mungkin. Berdasarkan data yang diperoleh, cara yang efektif untuk menyampaikan materi ini adalah melalui event panggung boneka.

Pendidikan toleransi bagi anak usia dini dapat disampaikan dengan memperkenalkan keberadaan perbedaan agama melalui cerita yang sederhana. Untuk dapat menarik perhatian, digunakan karakter dan warna-warna yang menunjukkan keceriaan, kebersamaan dan keislaman. Selain itu, penggunaan boneka juga dapat membuat anak merasa lebih terlibat dalam cerita.

Dengan diperkenalkannya keberadaan agama lain ini, diharapkan anak-anak muslim dapat memahami bahwa tidak ada yang salah dengan perbedaan. Agama merupakan sesuatu yang bersifat personal dan keyakinan masing-masing pemeluk harus dihormati. 


\section{DAFTAR PUSTAKA}

Hairuddin, Enni. (2014). Membentuk Karakter Anak Dari Rumah. Jakarta: Elex Media Komputindo.

Hawadi, Reni Akbar. (2001). Psikologi Perkembangan Anak Mengenal Sifat, Bakat, dan Kemampuan Anak. Jakarta: PT Grasindo.

Hidayat, Faiq. (2014, Desember 29). Yenny Wahid sebut kasus intoleransi beragama terbanyak di Jabar. Pesan disampaikan dalam http://www.merdeka.com/peristiwa/yenny-wahid-sebut-kasus-intoleransiberagama-terbanyak-di-jabar.html

Minkel, Walter. (1999). How To Do "The Three Bears" with Two Hands: Performing With Puppet. USA: American Library Association.

Noor, Any. (2009). Manajemen Event. Bandung: Alfabeta.

Septina P., Irma. Astika, Finka Fitri. Cahyaningsih, Alfyanti. (2012). Kerukunan Antar Umat Beragama. Diunduh $\quad 1 \quad$ April $2015 \quad$ dari http://staff.uny.ac.id/sites/default/files/PAl\%20Kerukunan\%20Hidup\%20Umat\%20B eragama-\%20Diskusi\%20Mahaiswa.pdf

Venus, Antar. Karyati S., Rema. Rakhmat, Jalaluddin. (2004). Manajemen Kampanye: Panduan Teoretis dan Praktis Dalam Mengefektifkan Kampanye Komunikasi. Bandung: Simbiosa Rekatama Media.

Wigan, Mark. (2009). Basic Illustration. London: Ava Publishing.

W.S., Titik, dkk. (2012). Kreatif Menulis Cerita Anak. Bandung: Nuansa. 